УДК 338.47:656.2(477)

\title{
АКТИВІЗАЦІЯ ДІЯЛЬНОСТІ ДЕРЖАВНИХ ІНСТИТУТІВ В ПРОЦЕСАХ РЕФОРМУВАННЯ ЗАЛІЗНИЧНОГО ТРАНСПОРТУ
}

\author{
Каличева Н.С., к.е.н., доцент (УкрдУЗТ), \\ Чередниченко О.Ю., к.е.н., доцент, професор (Інститут підготовки \\ юридичних кадрів для СБ Украӥни Національного юридичного \\ університету імені Ярослава Мудрого), докторант (УкрДУЗТ)
}

Державне регулювання економіки в умовах становлення та розвитку ринкового господарства потрібне для стабілізації та пристосування вітчизняної економічної системи до мінливих зовнішніх умов. Тому втручання держави у розвиток окремих галузей народного господарства, які виступають його основою, необхідне для усунення суперечностей $і$ неузгодженостей в ӥх діяльності. Вітчизняний транспортний сектор, основу якого складає залізничний транспорт, $\epsilon$ фундаментом ефрективного функціонування національної економіки й для забезпечення його ефективної роботи в сучасних ринкових умовах потрібна надійна та дієва підтримка державних інститутів.

Ключові слова: держава, залізничний транспорт, управління, функціонування, ринок транспортних послуг, державне регулювання

\section{АКТИВИЗАЦИЯ ДЕЯТЕЛЬНОСТИ ГОСУДАРСТВЕННЫХ ИНСТИТУТОВ В ПРОЦЕСАХ РЕФОРМИРОВАНИЯ ЖЕЛЕЗНОДОРОЖНОГО ТРАНСПОРТА}

\author{
Каличева Н.Е., к.э.н, доцент (УкрГУЖТ),
}

Чередниченко А.Ю., к.э.н., доцент, профессор (Институт подготовки юридических кадров для СБ Украины Национального юридического университета имени Ярослава Мудрого), докторант (УкрГУЖТ)

Государственное регулирование экономики в условиях становления и развития рыночного хозяйства необходимо для стабилизации и приспособления отечественной экономической системы к изменяюшимся внешним условиям. Поэтому вмешательство государства в развитие отдельных отраслей народного хозяйства, которые выступают его основой, необходимое для устранения противоречий и неувязок в их деятельности. Отечественный транспортный сектор, основу которого составляет железнодорожный транспорт, является фундаментом эффективного функционирования национальной экономики и для обеспечения его эффективной работь в современных рыночных условиях нужна надежная и эффективная поддержка государственных институтов.

Ключевые слова: государство, железнодорожный транспорт, управление, функционирование, рынок транспортных услуг, государственное регулирование

(C) Каличева Н.С., Чередниченко О.Ю.
Вісник економіки транспорту і промисловості № 64, 2018 


\title{
ACTIVATION OF THE ACTIVITIES OF STATE INSTITUTIONS IN THE PROCESSES OF REFORMING RAILWAY TRANSPORT
}

\author{
Kalicheva N.E., candidate of economic sciences, associate professor (USURT), \\ Cherednychenko O.U., PhD in Economics (Juridical Personnel Training \\ Institute for the Security Service of Ukraine, Yaroslav Mudryi National Law \\ University), doctoral student (USURT)
}

The transport sector is a key component of the efficient functioning of the national economy, and its governance should be effective.

New economic conditions which formed the level of use of a particular type of vehicle on the market, led to the immediate withdrawal position of road, water and air transport, which are more mobile and less infrastructure. Under these conditions, the farm complex infrastructure rail transport has to compete with private shipping companies other modes of transport that are able to respond quickly to market needs, using existing motor structure and infrastructure. The operation of the new transport services market leads to a revision of approaches in the management of the transport system of any country. Thus, during the last decades, due to the need to react quickly to changes in the market, there have also been changes in the structure of transport.

For a long time the activity of domestic rail transport was regulated by the state by coordinating its activities with different departments and structures. But the market of transport services places new demands on the functioning of the transport sector, should take account of globalization the world changes, new forms and patterns of international trade, the redistribution of global productive forces, the development of new services and others. All these factors lead to the need to review the role of rail transport in the market of transport services and to change their competitive position. Therefore, the further effective interaction between rail transport and the state should be based on new realities. Railway enterprises should be able to function on the market as independent commercial organizations, which will allow them to adapt themselves to market conditions and carry out economic activities in accordance with market needs. As a result, a significant proportion of railway companies becomes private, but as the world experience shows, railway companies are not able to independently operate and maintain such a complex industry in a reliable and operational state. Some countries, even, have returned the railways and transported back to their property. Thus, in order to ensure the truly harmonious operation of the rail transport in the market of transport services, it is necessary to create and implement effective mechanisms and tools for the close interaction of state authorities and transport companies.

The state's role in the effective development of rail transport is a significant, but not regulation state institutions capable of providing the appropriate level of competition in the industry, to increase the share of rail transport in total passenger and freight traffic, improve productivity and increase competitiveness and efficiency of the industry.

Key words: state, railway transport, management, operation, market of transport services, state regulation

Постановка проблеми та ї̈ зв'язки з науковими чи практичними завданнями. Дослідження проблем розвитку залізничного транспорту виводить на перший план симбіоз інтересів держави і галузі. Взаємодія цих двох найбільших суб'єктів господарювання виступає прикладом задоволення інтересів кожного 3 них. Залізничний транспорт забезпечує стабільне задоволення транспортних потреб народного господарства і населення; через податки i

Вісник економіки транспорту і промисловості № 64, 2018 
збори наповнює державний бюджет; створює нові робочі місця, знімаючи тим самим соціальну напруженість в суспільстві.

Держава, в свою чергу, регулює розвиток залізничного транспорту через такі важелі як загальна державна політика; фінансування перспективних проектів; тарифна політика; ліцензування діяльності; забезпечення транспортної безпеки, політика в області оплати праці залізничників та інші.

Діяльність

організаційних

інститутів держави має бути спрямованою на: активізація роботи по залученню додаткових інвестицій; формування фондів пільгового кредитування та фінансування, особливо найбільш перспективних та аварійних ділянок та напрямів; розвиток наукового, техніко-технологічного та кадрового потенціалу.

Зміна умов функціонування однієї системи призводить до зміни характеру іiі взаємодії з іншою системою. Мова, перш за все, йде про процеси реформування залізничної галузі. Реалізація програми реформування залізничного транспорту вимагає зміни характеру, масштабів, напрямків діяльності державних інститутів управління.

\section{Аналіз останніх досліджень $і$ публікацій. Питання державного} регулювання транспортного сектору, із виділенням специфіки функціонування залізничної галузі, розкрито в роботах Диканя В.Л., Гудкової В.П., Овчиннікової B.О., Матвієнка В.В., Собакаря А.О. та інших [1-6], де визначено, що на даний час державне регулювання в транспортній сфері, в основному, зводиться до застосування різноманітних підходів та методів, які стосуються технічного, антимонопольного та тарифного регулювання.

Відносно рекомендацій щодо структурних та інституційних змін, то вони видаються державними органами, як програмні документи подальшого стратегічного розвитку галузі із конкретними пропозиціями щодо шляхів вирішення тих чи інших питань ефективного розвитку залізничного транспорту. Але для забезпечення ефективного розвитку залізничної галузі, політика державного регулювання в цій царині має бути спрямована на інтеграцію вітчизняного транспорту в світову транспортну систему, що виражається через дотримання світових, зокрема європейських, норм функціонування всіх видів транспорту, в тому числі й залізничного.

Більшість науковців та дослідників питань ефективного розвитку залізничного транспорту виділяють наступні фактори, які має забезпечувати держава, а саме [7; 8; 9]: ринкову та цінову доступність; надійність, безпеку та екологічність; відповідність національним та міжнародним вимогам; державну підтримку та регулювання.

Метою cmammi $\epsilon$ дослідження напрямів активізації діяльності державних інститутів в процесах реформування залізничного транспорту.

Викладення основного матеріалу дослідження. Нові економічні умови, котрі формують рівень використання того чи іншого виду транспорту на ринку, призвели до виведення на першочергові позиції автомобільних, водних та повітряних перевезень, які $\epsilon$ більш мобільними та менш інфраструктурними. За таких умов, складному інфраструктурному господарству залізничного транспорту доводиться конкурувати із приватними перевізними компаніями інших видів транспорту, які спроможні швидко реагувати на потреби ринку, використовуючи наявний руховий склад та інфраструктуру. Й в цьому процесі держава повинна приймати більш активну участь.

Жорстке державне регулювання діяльності залізничного транспорту характерно для тих країн, в яких зародження i подальший розвиток залізничної галузі здійснювалося (і багато в чому продовжує здійснюватися) за рахунок державних коштів, через

Вісник економіки транспорту і промисловості № 64, 2018 
фінансування державної вертикальноінтегрованої транспортної монополії (Великобританія, Німеччина, Російська Федерація, Республіка Казахстан, в деяких штатах Австралії, США і т.д.).

Взагалі, основною роллю державного регулювання та управління $\epsilon$ створення таких умов для функціонування суспільства, реалізація яких сприятиме його соціальному, економічному, технічному й іншим напрямам розвитку та буде майже непомітною. Адже чітке виконання державними інститутами своїх обов'язків сприяє ефективному розвитку національного добробуту країни. Тим більше, що держане управління виступає узгоджуючим чинником щодо врегулювання всіх видів суперечностей між різними групами суспільства і роль державних інститутів, за таких умов, $\epsilon$ досить важливою [10].

Загальна державна політика розвитку залізничного транспорту регламентується державною цільової моделлю розвитку галузі залізничного транспорту [11]. Хоча ця програма не дає конкретних індикаторів економічного розвитку галузі, проте висуває цілком слушні принципові положення і настанови щодо структурних змін підвищення економічної стійкості галузі, розвитку ринку транспортних послуг на основі іiі реструктуризації.

Основу подальшого організаційноекономічного розвитку залізничного транспорту формують наступні інструменти транспортної політики: інтенсивне запровадження енергоощадних технологій; збільшення рівня державного інвестиційного забезпечення; підтримка соціального забезпечення робітників; змінення підходів до перевезення небезпечних вантажів; підтримка вітчизняного виробника; посилення співпраці 3 іноземними партнерами; запровадження міжнародних норм та правил у вантажних та пасажирських перевезеннях та інше.

Залізничний транспорт потребує особливої уваги з боку держави, оскільки залишається лідируючим суб'єктом на ринку транспортних послуг. За даними Держслужби статистики за 2017 рік щодо обсягів перевезень вантажів за видами транспорту (без урахування території АР Крим, та ОРДЛО) частка залізничного транспорту становить $53 \%$ в обсягах перевезень вантажів і 56 \% у вантажообігу (без трубопровідного - $65 \%$ та $81 \%$ відповідно) (таблиця 1).

Таблиия 1

Обсяг роботи транспорту України у 2017 роичі

\begin{tabular}{|l|c|c|c|c|}
\hline \multirow{2}{*}{\multicolumn{1}{|c|}{ Показник }} & \multicolumn{2}{|c|}{ Вантажообіг } & \multicolumn{2}{c|}{ Перевезено вантажів } \\
\cline { 2 - 5 } & млн. т-км & \% до 2016 p. & млн. т & $\%$ до 2016 p. \\
\hline Транспорт разом, у т. ч. & 343057 & 105,8 & 635,9 & 101,8 \\
\hline - залізничний & 191914 & 102,3 & 339,5 & 98,9 \\
\hline - автомобільний & 41179 & 108,4 & 175,6 & 104,7 \\
\hline - водний & 4257 & 106,3 & 5,9 & 88,1 \\
\hline - трубопровідний & 105434 & 111,7 & 114,8 & 107,6 \\
\hline - авіаційний & 273 & 120,5 & 0,1 & 110,5 \\
\hline
\end{tabular}

У 2017 році за всіма видами транспорту спостерігається збільшення обсягів вантажообігу, але по залізничному та водному транспорту обсяг перевезених вантажів скорочувався. За 2017 рік залізницями перевезено 339,6 млн. тон вантажів, що менше за аналогічний період минулого року на 3,9 млн. тон, або на 1,1\%.
При цьому показник вантажообігу більше за 2016 рік на 2,3\% і склав 191914 млн. тKM.

На залізничному транспорті ситуація 3 обсягами перевезень стала продовженням тенденції, що склалася за останні роки (рисунок 1).

Вісник економіки транспорту і промисловості № 64, 2018 


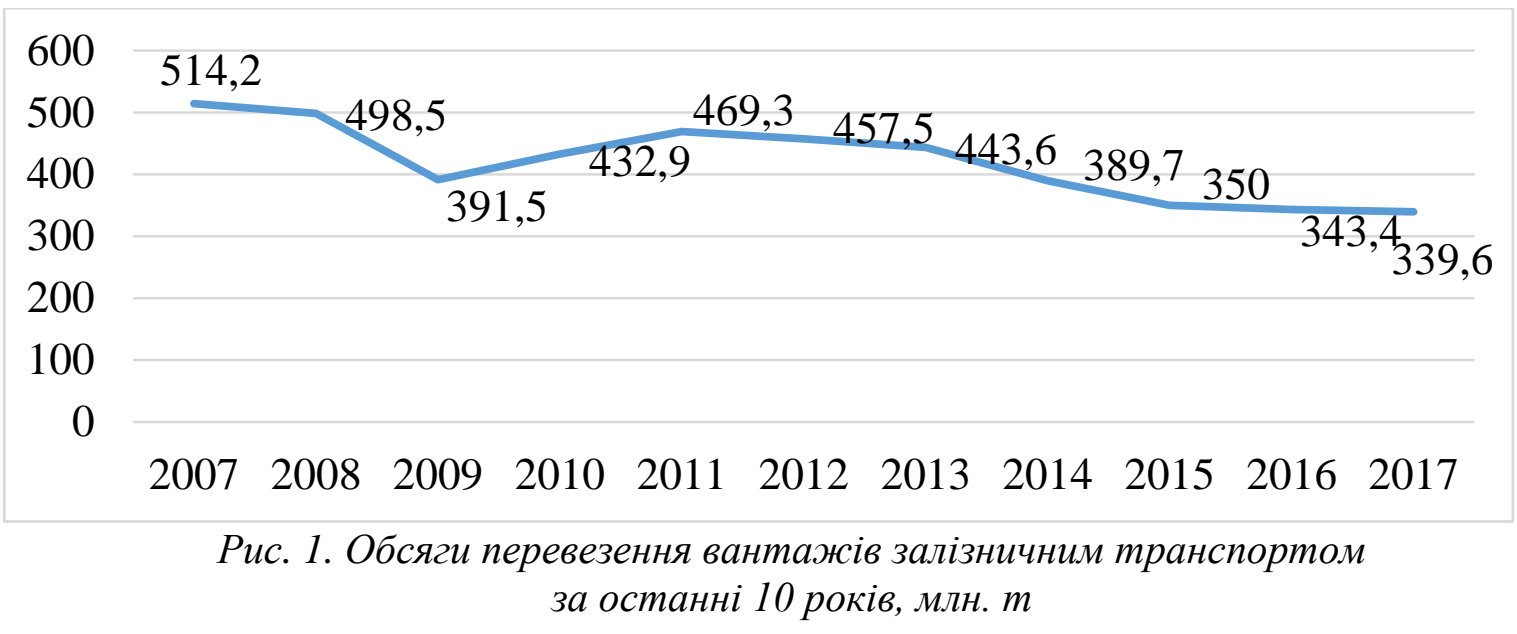

Ринок транспортних послуг висуває нові вимоги до функціонування транспортного сектору, що має враховувати глобалізаційні світові зміни, створення нових форм та моделей у міжнародній торгівлі, перерозподіл світових виробничих сил, розвиток нових видів послуг та ін. Всі ці фактори призводять до потреби переглядати роль залізничного транспорту на ринку транспортних послуг та до зміни їх конкурентних позицій [12].

$$
3 \text { метою недопущення }
$$

дискримінації соціальних пасажирських перевезень держава повинна виступати їх державним замовником, приділяючи особливу увагу дотаційним регіонам. При цьому не можна відмовлятися від плацкартних вагонів, які користуються особливим попитом у соціально незахищених груп населення. Під пильною увагою держави повинні залишатися i приміські перевезення за рахунок встановлення правил на формування державного замовлення із перевезення пільгових категорій, як на рівні країни, так і на місцевому, та регулювання соціальноорієнтованих тарифів, що сприятиме розвитку бізнесу в цій сфері за рахунок прагнення виконання державного замовлення.

Одним 3 основних важелів державного регулювання залізничної галузі повинно стати пряме фінансування. Сьогодні фінансовий стан залізниць свідчить про недостатність відповідних коштів. Потреба в коштах, необхідних для виконання секторальної політики складає приблизно 20 - 30 млрд. грн щорічно: на оновлення рухомого складу - 15-20 млрд. грн; на реконструкцію та технічне переоснащення об'єктів інфраструктури, рухомого складу - 4-6 млрд. грн; на реалізацію інвестиційних проектів близько 2 млрд грн. Відповідно до плану інвестиційних витрат на придбання рухомого складу, модернізацію та придбання нематеріальних активів в 2018 році складуть 3625, 7 млн. грн [13].

Фінансові важелі держави активно використовуються у світовій практиці. Серед останніх прикладів $є$ схвалення Свропейської комісії програми щодо державної підтримки операторів, які переключають вантажі 3 автомобільного транспорту на залізничний або водний в сполученнях $з$ морськими портами Бельгії. Програма вартістю 70 млн євро триватиме до жовтня 2023 г. Вона передбачає виплату субсидій операторам перевезень вантажів по залізничних i водних шляхах. Одиницею розрахунку субсидії є потяг або контейнер. Ініціатива покликана компенсувати додаткові витрати операторів, пов'язані 3 накопиченням вантажів для формування відправок економічно виправданого об'єму. За заявою Єврокомісії, вона необхідна, щоб мотивувати замовників транспортних послуг до вибору видів транспорту 3 меншим негативним впливом на навколишнє середовище i сприяти 
зниженню навантаження на автомобільні дороги [14].

В цілому реалізація інвестиційних проектів, що фінансуються за рахунок бюджетних коштів, спрямована на соціально-економічний розвиток України в частині транспортної інфраструктури державної власності.

Вчені акцентують увагу на те, що впродовж ряду років держава не здійснювала фінансування капітальних вкладень в національні залізниці. Нажаль оновлення рухомого складу на вітчизняних залізницях йде дуже повільно. Так у 2016 році було побудовано 370 піввагонів, у 2017 році - 2604. У 2018 році планується побудувати 3600 піввагонів. Станом на кінець 2 кварталу 2018 року побудовано 1454 піввагона.

На сьогодні потреби залізничного транспорту в інвестиціях задовольняються лише на $25-30 \%$. В той час як обсяги інвестицій у розвиток залізничного транспорту в розвинених країнах сягають $10-15 \%$, в Україні інвестиції становили $7,1 \%$ [15].

Вирішити проблему оновлення основних фондів здатні додаткові фінансові кошти. Але в Україні вартість фінансових ресурсів на внутрішньому ринку $\epsilon$ досить високою. При цьому в реальному вираженні через високу інфляцію ставки по депозитах залишаються негативними, що знижує стимули заощадження i не сприяє підвищенню ефективності кредитування. Висока вартість кредиту виступає головним чинником, що обмежує попит нефінансових корпорацій на кредит як джерело фінансування інвестиційної діяльності. Рівень рентабельності операційної діяльності більшості підприємств реального сектору економіки не перевищує $15 \%$, що робить економічно невигідним фінансування інвестиційної діяльності за рахунок кредиту. Банкам набагато вигідніше надавати довгострокові кредити населенню, оскільки відсоткова ставка за такими кредитами $\epsilon$ значно вищою, що в кінцевому випадку забезпечує банку отримання більшого прибутку [16]. В якості інвесторів можуть виступати і місцеві органи влади. В зв'язку 3 цим необхідно нагадати досвід західноєвропейських країн, де, наприклад, землі (в Німеччині), регіони (у Франції) i інші місцеві державні органи прийняли на себе обов'язки по фінансуванню послуг місцевого залізничного транспорту в обмін на отримання щедрої компенсації від центральних державних органів.

В умовах обмеженості інвестиційних ресурсів доцільно більш активне застосування інструменту лізингу для задоволення потреб залізничного транспорту в рухомому складі.

Враховуючі, що характерними рисами сучасного стану залізниць $\epsilon$ високий рівень зносу основних фондів, саме держава повинна стимулювати питання щодо приватизації деяких об'єктів, залучення інвестицій та технологічної модернізації в галузі. Головним напрямком цієї роботи $\epsilon$ продовження виведення зі структури державного залізничного транспорту i передача в муніципальну власність об'єктів житлово-комунального господарства, акціонування i приватизація загально будівельних організацій, ремонтних заводів, підприємств торгівлі i громадського харчування, а також інших підприємств і об'єктів непрофільного призначення, безпосередньо не пов'язаних 3 перевезеннями. Доходи від продажу, здачі в оренду або розпорядження якимнебудь іншим способом майна, що належить підприємствам залізничного транспорту, а також кошти від приватизації повинні бути спрямовані на інвестиційні цілі.

Підприємства залізничної галузі повинні мати можливість функціонувати на ринку як самостійні комерційні організації, що дасть їм змогу самостійно пристосовуватися до ринкових умов та здійснювати господарську діяльність відповідно до потреб ринку.

3 іншого боку, у більшості країн, залізнична інфраструктура історично 
зберігає державну власність. Невдала спроба Великобританії приватизувати залізничний інфраструктурний комплекс показала не готовність приватних інвесторів забезпечити адекватний обсяг інвестиційних коштів, необхідних для підтримки надійного функціонування i подальшого розвитку об'єктів залізничної інфраструктури, на шкоду власним інтересам, спрямованим на отримання максимальної прибутковості на інвестований ними капітал [17].

Прерогативою

держави залишається тарифне регулювання. Слід відмітити, що у національної валюті тарифі на перевезення щорічно зростають. Але у доларовому еквіваленті тарифи мають тенденцію скорочення.

Щоб ситуація була більш наочною, слід навести індекс цін виробників промислової продукції (рисунок 2).

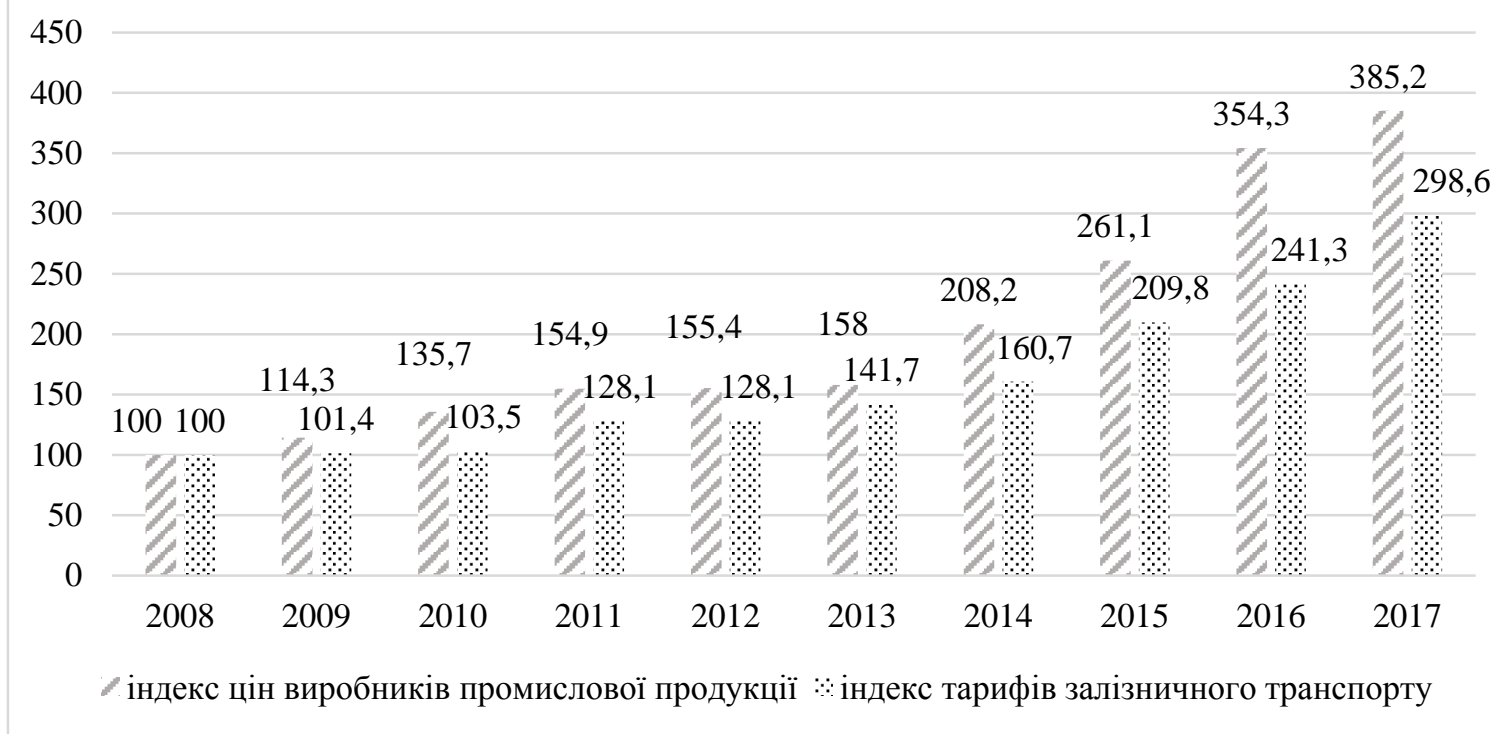

Рис. 2. Індекси ціін виробників промислової продукиії та тарифів на перевезення вантажів залізничним транспортом, \% до 2008 року

Як бачимо 3 рисунка 2 ціни виробників промислової продукції зростають більш швидко ніж залізничні тарифи. Це оказує вплив на фінансовий стан транспорту у цілому.

В системі залізничного транспорту повинні бути виділені в якості структурних підрозділів види діяльності, які $\epsilon$ природно-монопольними i потенційно конкурентними. У монопольному секторі буде здійснюватися державне регулювання тарифів, а в конкурентному - їх поетапна лібералізація в міру розвитку конкуренції на ринку пасажирських та вантажних перевезень. Поступове звуження сфери тарифного регулювання стане значним стимулом для інвесторів вкладати кошти в розвиток залізничного транспорту.
В якості інструменту, здатного забезпечити узгодження фінансових інтересів держави і підприємств залізничного транспорту деякі науковці [15] пропонують застосувати регресійне оподаткування прибутку. Застосування регресійного оподаткування прибутку, за висновками авторів, $є$ фактором стимулювання процесу технологічного та інноваційного розвитку підприємства оскільки сприятиме зниженню ставки спадкування при щорічному зростанні прибутку підприємства. Зниження ставки оподаткування здійснюється безперервно i дає можливість підприємству направляти додаткові інвестиції для здійснення технічно-технологічного оновлення підприємств залізничного транспорту. 
Суттєве

значення

має

вдосконалення податкового законодавства, зокрема, необхідно прийняти поправки, що усувають подвійне оподаткування пасажирських компаній по оборотним податках [18]. Крім того, необхідно зберегти податкову базу відповідних областей при проведенні структурних перетворень. Тим самим 3 боку відповідних територій буде забезпечена політична підтримка реформ. Внесення до чинного законодавства цих, і інших, змін дадуть можливість сформувати необхідну правову базу для реалізації планів по структурному реформування залізничного транспорту.
Безумовно, слід звернути увагу на законотворчу функцію держави в сфері забезпечення транспортної безпеки. В умовах збереження конфлікту на сході країни це особливо актуально. Значу роль у цьому процесі повинні виконати місцеві адміністрації. Як показує успішний закордонний досвід, самостійне місце займають тут транспортні асоціації, неурядові фонди та інші суспільні інститути. Побудова єдиної системи транспортної безпеки має носити комплексний характер.

Стан безпеки, пов'язаний iз залізничними транспортними подіями, за останні роки наведено у таблиці 2 [19].

Таблиия 2

Кількість залізничних транспортних подій в структурі ПАТ «Укрзалізниця»

\begin{tabular}{|l|c|c|c|c|c|c|}
\hline Вид транспортної події & 2011 & 2012 & 2013 & 2014 & 2015 & 2016 \\
\hline Катастрофа & 0 & 0 & 0 & 0 & 0 & 0 \\
\hline Аварія & 0 & 1 & 0 & 0 & 0 & 1 \\
\hline Серйозний інцидент & 31 & 27 & 20 & 19 & 27 & 31 \\
\hline Інцидент & 735 & 736 & 698 & 654 & 575 & 537 \\
\hline Всього & 766 & 764 & 718 & 673 & 602 & 569 \\
\hline
\end{tabular}

Кількість залізничних транспортних подій має тенденцію до зменшення. Але треба відмітити, що це здійснюється на фоні скорочення обсягів перевізної роботи. За шість останніх років загальна кількість залізничних подій скоротилася більш ніж на $25 \%$. В той же час відправлення вантажів залізничним транспортом за той же час скоротилося на $27 \%$, а відправлення пасажирів - на $11 \%$.

По відношенню до галузі державне управління за всіма його формами повинно бути ефективним. Відповідно до [20] для підвищення ефективності державного управління необхідно дотримуватися наступних принципів: консолідація державної політики відповідно до потреб народного господарства у державному управлінні; отримання реальних результатів від управлінського процесу; децентралізація певних повноважень шляхом передачі їх на нижчі рівні управління або в приватний сектор; застосування нових управлінських, навіть не традиційних, підходів, особливо в сфері кадрової політики.

Bci перераховані вище принципи мають функціонувати в тісній взаємозалежності, що сприятиме формуванню самокерованої системи державного управління [21]. А для сфери державного управління застосування такого підходу $є$ найбільш ефективними, бо в його основу покладена спроможність системи бути відкритою для змін та нововведень, практичних доповнень та коректив. Тому, ефективність державного управління, особливо в транспортній сфері, має грунтуватися на таких підходах: соціальна орієнтованість; комплексність, що включає вирішення економічних, соціальних, політичних, технологічних, виробничих, екологічних, регіональних, культурних та інших проблем в країні; оптимальність, особливо при прийнятті рішень, які враховують, як національні інтереси, так і - регіональні;

Вісник економіки транспорту і промисловості № 64, 2018 
інформатизація; функціональна та структурна єдність.

У завершенні слід підкреслити, що підприємства залізничного транспорту - це життєве важливі суб'єкти господарювання в економічному комплексі держави, які сприяють безперебійному функціонуванню всіх галузей економіки, міжрегіональним та міжнародним культурним зв'язкам, соціальним перетворенням, міжнародному туристичному співробітництву та торгівлі, а також забезпечують ii економічну безпеку та цілісність. Тому держава повинна приймати більш активну участь у розвитку цей важливої галузі економіки. Слід пам'ятати, що 1 долар інвестицій в інфраструктуру залізниць дає 2-3 долара приросту номінального ВВП, а створення 1 робочого місця у транспортному секторі призводить до створення 6 робочих місць в інших секторах.

\section{СПИСОК ВИКОРИСТАНИХ ДЖЕРЕЛ}

1. Дикань В.Л. Сутнісні аспекти конкурентоспроможності національної економіки / В.Л. Дикань, О.Г. Кірдіна // Вісник економіки транспорту i промисловості: збірник наукових праць. - Х.: УкрДАЗТ, 2009. - № 28. - С. 13-20.

2. Дикань В.Л. Удосконалення механізмів державного управління розвитком залізничної галузі України у євро інтеграційному просторі/ В.Л. Дикань, Г.Є. Островерх// Вісник економіки транспорту i промисловості : збірник наукових праць. - Х. : УкрДУЗТ, 2018. - № 62. - C. 11-19.

3. Гудкова В. П. Структурнофункціональний аналіз державного регулювання розвитку залізничного транспорту / В. П. Гудкова, Ю. О. Тютюн // Залізничний транспорт : зб. наук. праць ДЕТУТ. - 2015. - Вип. 33. - С. 70-77. (Серія "Економіка і управління ").

4. Овчиннікова В.О. Особливості державного регулювання розвитку залізничного транспорту в Україні [Електронний ресурс]. Економіка та суспільство. - 2017. - №12. - С. 129-135. Режим доступу: http: // economyandsociety.in.ua.

5. Матвієнко В.В. Основні напрями державного регулювання залізничним транспортом України / В.В. Матвієнко // Актуальні проблеми державного управління. Серія Державне управління: зб. наук. пр. - Х. : «Магістр», 2016. №1(49). - C. 19-25/

6. Собакарь А.О. Державна політика транспортної безпеки України: актуальні питання реалізації/ А.О. Собакарь, В.М. Бечасний// Віче. - 2010. - №4. - С. 2-5.

\section{7. Сайт Міжнародного}

транспортного форуму [Електронний pecypc]. - Режим доступу: https://www.itfoecd.org/sites/default/files/docs/12keystat 2017.pdf

8. Україна у цифрах у 2017 році: статистичний збірник/ за редакцією I. Є. Вернера. - К.: ТОВ «Видавництво Консультант», 2018 - 241 с.

9. Каличева Н.Є. Методологічні аспекти підвищення конкурентоспроможності підприємств залізничного транспорту за рахунок управління конкурентними позиціями/ Н.Є. Каличева// Науковий вісник Херсонського державного університету. Серія: Економічні науки. - Херсон, 2017. Вип. 27. - Ч. 1. С. $139-142$

10. Каличева Н.Є. Організація управління на підприємствах залізничного транспорту в сучасних умовах/ H.Є. Каличева// Вісник економіки транспорту i промисловості: збір. наук. праць - Харків, УкрДАЗТ. - 2014. - № 45. - С. 167- 170.

11. Державна цільова програма реформування залізничного транспорту на 2010-2019 роки [Електронний ресурс]: постанова КМУ від 16.12.2009 № 1390. Режим http://zakon.rada.gov.ua/laws/show/13902009-\%D0\%BF- Назва с екр. - (Дата звернення: 20.11.2018)].

12. Сивый В.Б. К вопросу обоснования необходимости проведения структурной реформы в транспортной отрасли / В.Б. Сивый, О.М. Козырь //

Вісник економіки транспорту і промисловості № 64, 2018 
Вісник економіки транспорту i промисловості : зб. наук. праць, - Харків : УкрДАЗТ. - 2005. - № 9-10. - С. 140-145

13 Соломніков, І.В. Інвестиційне забезпечення техніко-технологічного оновлення підприємств залізничного транспорту / I.B. Соломніков // Вісник економіки транспорту і промисловості. - № 60, 2017. - С. 223 -228.

14. Еврокомиссия одобрила программу поддержки перераспределения грузов в пользу железнодорожного и водного транспорта https://railwaypublish.com/news/7858-evrokomissiiaodobrila-programmy-podderjkipereraspredeleniia-gryzov-v-polzyjeleznodorojnogo-i-vodnogo-transporta.html

15. Соломніков, I.B. Державна підтримка техніко-технологічного оновлення підприємств залізничного транспорту [Електронне наукове видання]/ I.B. Соломніков // Мукачівський державний університет. - Випуск № 6/2016. - C. 215-219. - режим доступу: http://economyandsociety.in.ua/journal/6_ukr 136.pdf

16. Непран, А.В. Роль запозичень у фінансуванні інвестиційної діяльності підприємств реального сектору економіки / А.В. Непран, I.C. Тимченко, Н.М.
Каменева // Вісник економіки транспорту і промисловості. - № 60, 2017. - С. 216-223.

17. Railway Reform in Germany: Restructuring, Service Contracts, and Infrastructure Charges [Text] / Von der Fakultät VII - Wirtschaft und Management der Technischen Universität Berlinzur Erlangung des akademischen Grades, Berlin, 2008 - 236 p.

18. Матвеева Н.А. Инновационные модели инвестиционной стратегии управления предприятиями железнодорожного транспорта // Бюллетень транспортной информации, №9 (171), сентябрь 2009, С. 14 -17.

19. Лапін П. В. Виробничі загрози економічної безпеці підприємств залізничного транспорту [Текст] / П. В. Лапін // Вісник економіки транспорту i промисловості. - № 55, 2016. - С. 41 - 50

20. Цвєтков B. В. Державне управління: основні фактори ефективності (політико-правовий аспект)/ В.В. Цвєтков. - Х. : Право, 1996. -192 с.

21. Ефективність державного управління в умовах реформ: наук. розробка / Ю. В. Ковбасюк, Н. Г. Джинчарадзе, Ю. П. Сурмін [та ін.]. - К. : НАДУ, 2014. - 76 с.

DOI 10.18664/338.47:338.45.v0i64.149573

УДК 656.078

\title{
ТЕОРЕТИЧНІ ЗАСАДИ МОДЕРНІЗАЦІЇ ПІДПРИСМСТВ ЗАЛІЗНИЧНОГО ТРАНСПОРТУ УКРАЇНИ
}

\author{
Корінь М.В., к.е.н., доцент, \\ Сендюк В.Е., магістр, \\ Муквіч О.С., магістр (УкрДУЗТ)
}

В статті вивчено теоретичні основи модернізації, щуо дозволило представити авторське розуміння даного терміну. Запропоновано під модернізацією підприємств залізничного транспорту розуміти прочес якісних перетворень на підприємствах галузі за рахунок освоєння сучасних технологій організації транспортного прочесу та оновлення інфраструктури, спрямованих на підвищення енего- і ресурсоефективності, 